\title{
DEVELOPING ISSUE-BASED TEACHING MATERIALS TO IMPROVE STUDENT LEARNING OUTCOMES IN FRESHWATER BIOLOGY COURSE
}

\author{
Syaris Kamaludin*, Hertien Koosbandiah Surtikanti, and Wahyu Surakusumah \\ Biology Education Study Program, Faculty of Mathematics and Education Natural Sciences, \\ Indonesia University of Education, Bandung, West Java, Indonesia \\ *Corresponding e-mail: kamal_sariz@yahoo.com
}

\begin{abstract}
One of Freshwater Biology course problems is that the students were unable to understand the environmental phenomena around them. The aim of this study was to develop issue-based teaching materials in Freshwater Biology course to improve the students' understanding about the environmental phenomena through their learning outcomes. This research and development used three phases of the $4 D$ model developed by Thiagarajan, namely define, design, and development. The development results were validated by content and media experts. The design used for a pilot test, which was conducted among 20 students, was one group pretest-posttest design; meanwhile, the data analysis technique used was the independent $t$-test. It can be concluded that the teaching materials developed was valid with the average validation score as high as 79.83\%. In addition, there was a significant improvement (sig. 0.000) of student learning outcomes after attending the course which implementing the issue-based teaching materials developed. Thus, the implementation of issue-based teaching materials is recommended in Freshwater Biology course due to its potential in improving students' learning outcomes.
\end{abstract}

Keywords: Biology, issue-based materials, learning outcomes

(C) 2018 Department of Biology Education, FTTE, University of Muhammadiyah Malang, Indonesia

\section{INTRODUCTION}

Biology is one science subject which often considers have various abstract concepts for students (Çimer, 2012; Etobro \& Fabinu, 2017; Ogunkola \& Samuel, 2011; Topçu \& ŞahinPekmez, 2009). The assumption will more perceive by students if the learning process relies solely on textbooks. In fact, the object of biological studies is various environmental phenomena and organisms that exist around the student. Students will engage to learn if the source of learning is a phenomenon or issue in their environment (Brickell, Hedberg, Ferry, \& Harper, 2001; Elder, 2015; Hill, 1998; Permana, Suwono, \& Listyorini, 2016), which is familiar with them. By developing teaching material based on phenomenon or issue in students' environment, will encourage them to explore biological concepts.

The utilization of relevant learning resources will be achieving systematic learning to design effective learning. According to the Ministry of National Education, teaching materials play an important role in the learning process (Bahri,
Syamsuri, \& Mahanal, 2016) and can optimize the learning outcome (Susilana \& Riyana, 2009). Regarding to that situation, the quality of learning will increase when the learning component can be optimally empowered, by making improvements and updates on the learning materials.

Improvement of learning material can be arranged using a phenomenon or issue (Nuangchalerm, 2009; Nuangchalerm \& Kwuanthong, 2017). In this type of learning that combines the symptoms that occur in the environment with learning content, students' science literacy can increase (Nuangchalerm, 2009; Presley et al., 2013). Problems in student environmental have a prominent linking to the biological concept, such as ecology, conservation, and extinction issue (Presley et al., 2013). Therefore, the development of learning material based on issues is a good alternative in biology learning.

Freshwater Biology course is one of the specialization courses in Biology Education of Indonesia University of Education. The scope of Freshwater Biology includes freshwater 
zonation, freshwater quality and its relationship (physical, chemical and biological factors), and freshwater biota (autotroph and heterotroph) in static water (called lentic) and flowing water (called lotic). Based on the preliminary research, there was an absence of specific teaching materials to discuss the bio-indicators plankton in some freshwater ecosystem (e.g. lake, pond), especially in West Java area. Student only did a critical analysis of articles, rather than explore the issues around their environment. This condition tends students to less aware of the potential problem or issue of their area.

Various research and development have been conducted by previous researchers to improve the process of biology lectures (Fauzi, 2017; Miharja, Syamsuri, \& Saptasari, 2015; Widiansyah, Indriwati, Munzil, \& Fauzi, 2018). However, the research and development that conducted on Fresh Water biology course is still hard to find. In addition, until now, the development of issue-based teaching materials is still rare to find in Indonesia. Therefore the development of issue-based teaching materials in Freshwater Biology course needs to be established. Moreover, according to Hunaepi, Kurnia, and Firdaus (2014), the common difficulties confronted in ecological learning are the lack of students' ability to examine and understand phenomena and issue in nature using ecological science. Therefore, the researchers chose the right location as the enrichment of teaching materials on Freshwater Biology course that is Situ Bagendit Lake in Garut, West Java Province, Indonesia.

\section{METHOD}

This study actually was divided into two steps; first step was a preliminary study to determine the quality of freshwater in Situ Bagendit Lake; the second was development of issue-based teaching materials to improve students' learning outcome in Freshwater Biology course. However, this paper is more focus on reporting the second step. The first step was conducted in Situ Bagendit Lake, whereas the second step was conducted in the Faculty of Mathematics and Education Natural Sciences, Indonesia University of Education. The study begins with a preliminary study (step 1) about the quality of freshwaters in Situ Bagendit Lake based on bio-indicator using plankton. Then, the result of the preliminary study was used as a material for planning the preparation of developing teaching materials.

The development research (step 2) only consists of 3 phases of 4D Thiagarajan's model. The stages in this study, namely (1) define phase, including the analysis of lecture unit, materials, indicators, as well as the formulation of learning objectives; (2) the design phase, including the selection of the format, and the preparation of the initial design (product draft); (3) development phase, including the validation of product draft by the experts, then revised the draft, and conduct a pilot test.

In a pilot test, the design used in this stage was one group pretest post-test design. The measured parameter was learning outcomes, i.e. students' concept understanding and problem solving skills. Problem-solving skills consist of five aspects including formulating problems, stating hypotheses, testing hypotheses, describing conclusions and applying conclusions.

The students would get a pretest to measure their learning outcome before the implementation of teaching materials. After the implementation of teaching materials, students get a post-test to determine the improvement of student learning outcomes. Then, the data were analyzed using the normalized gain ( $\mathrm{N}$-gain) and the independent t-test. The study was conducted in July until September 2017 with the subjects were students who toke Freshwater Biology courses. The sampling technique used was purposive sampling.

\section{RESULTS AND DISCUSSION}

\section{Definition Phase}

Observation results in Situ Bagendit Lake

Observation of water quality in Situ Bagendit Lake conducted first before developed into teaching materials. Three areas of Situ Bagendit Lake were measured as the observation station; inlet, middle, and outlet. The measurements of physical and chemical factors, includes temperature, turbidity, $\mathrm{pH}$, depth, Dissolved Oxygen (DO), free carbon dioxide, and Biochemical Oxygen Demand (BOD). The observation result presented in Table 1 (physical-chemical factors of freshwater in Situ Bagendit Lake) and Table 2 (freshwater quality based on plankton as bioindicators in Situ Bagendit Lake). 
Table 1. The measurement result of physical-chemical freshwater condition in Situ Bagendit Lake

\begin{tabular}{clcccc}
\hline \multirow{2}{*}{ No. } & \multicolumn{1}{c}{ Parameters } & Quality standart & \multicolumn{3}{c}{ Station } \\
\cline { 4 - 6 } & & $28-30$ & 26.51 & Middle & Outlet \\
\hline 1 & Temperature $\left({ }^{\circ} \mathrm{C}\right)$ & - & 18.71 & 25.44 & 25.18 \\
2 & Turbidity $(\mathrm{cm})$ & - & 142 & 27.76 & 29.31 \\
3 & Depth $(\mathrm{cm})$ & $6-9$ & 3.26 & 35 & 174 \\
4 & $\mathrm{pH}$ & $>4$ & 3.81 & 3.79 & 6.5 \\
5 & $\mathrm{DO}(\mathrm{mg} / \mathrm{l})$ & & 8.18 & 10.2 & 6.76 \\
6 & $\mathrm{CO}(\mathrm{mg} / \mathrm{l})$ & 3 & 3.11 & 3.03 & 2.84 \\
7 & $\mathrm{BOD}(\mathrm{mg} / \mathrm{l})$ & & & & \\
\hline
\end{tabular}

(Source: Government regulation of The Republic of Indonesia Number 82 year 2001 on water quality management and water pollution control, 2001).

Table 2. Water quality in Situ Bagendit Lake based on plankton as bio-indicators

\begin{tabular}{lcccc}
\hline \multirow{2}{*}{ Stasiun } & \multicolumn{3}{c}{ Situ Bagendit pollution rate } & \multirow{2}{*}{ Water quality } \\
\cline { 2 - 4 } & Type composition & Index of diversity & The level of pollution & Poor \\
Inlet & Low & Low & Medium & Poor \\
Middle & Medium & Medium & Medium & Moderately good \\
Outlet & Medium & Medium & Low & Mow \\
\hline
\end{tabular}

The turbidity value of Situ Bagendit Lake ranged from $18.71-23.31 \mathrm{~cm}$. The lowest brightness was in the inlet area $(18.71 \mathrm{~cm})$, whereas the brightest area was an outlet area $(29.31 \mathrm{~cm})$. The turbidity of water bodies is influenced by the water clarity. The more turbid waters showed the higher concentration of total suspended solids. Turbidity can be caused by the presence of abiotic materials such as sediment and pollution waste, or the high concentrations of biota such as phytoplankton (Feng, Hu, Chen, Tian, \& Chen, 2012; Johan, 2011; Monica Z. Bruckner, 2018). Based on the data, the water in Situ Bagendit Lake was clear and penetration of light entering is high. This is supported also by the value of depth range from $142-174 \mathrm{~cm}$.

Value the potential of Hydrogen $(\mathrm{pH})$ at each area in Situ Bagendit Lake ranged from 3.26 to 6.5. Based on the data obtained, the $\mathrm{pH}$ value in Situ Bagendit Lake waters is at the lowest allowable range. This is supported by the opinions of Johan (2011) who states the degree of acidity $(\mathrm{pH})$ of water is one of the chemical properties of water affecting the growth of plants and aquatic animals and could use as a guide to examine the quality of water environment as a living environment.

Dissolved oxygen in Situ Bagendit Lake waters ranged from 4.23 to $6.76 \mathrm{mg} / \mathrm{L}$. The high oxygen dissolved in the outlet compared to other stations related to the low temperature of these waters. This statement is accordance with Johan (2011) who informed dissolved oxygen in waters can come from the air and from the movement of water, the largest source of dissolved oxygen in the waters comes from the process of photosynthesis of water plants. The water-soluble oxygen levels that can still be tolerated by aquatic organisms especially phytoplankton are not less than $5 \mathrm{mg} / \mathrm{l}$.

The free carbon dioxide value in Situ Bagendit Lake waters ranged from 4.84-10.12 ppm. The highest free $\mathrm{CO}_{2}$ was found in the inlet, the middle ranged from 8.18 to $0.12 \mathrm{ppm}$, and the lowest was in the outlet $(4.48 \mathrm{ppm})$. The high content of $\mathrm{CO}_{2}$ in the waters can lead to disruption of marine life. Table 2 describes the quality of Situ Bagendit Lake waters was poor to moderately good. The inlet and the middle part were the stations with medium pollution level, besides the outlet was moderate. Medium levels of contamination in the inlet and middle portions show poor water quality.

\section{Analysis of material developed for issue-based teaching materials}

The material developed for issue-based teaching material was the use of plankton as bio-indicator which refer to the Achievement of Study Program (ASP) that is: students are able to utilize the expertise in the field of biology with the aim of solving problems in the community adaptively (LO 3), mastering the concept, principles, theories, and laws of biological science to solve scientifically (LO 6), and capable of developing biological science through research so as to contribute to problem solving in society (LO 7). While the learning achievement was the student is able to utilize plankton as bio-indicator to solve the freshwater ecological problem or issue. 
The learning achievement related to general skill is to make decisions appropriately to solve the problem related to freshwater ecosystem based on the analysis of information and data. In more detail, the analysis results are presented in Table 3. Based on Table 3, the teaching materials consist of 4 sub-materials that are, 1) aquatic physics factors and measurement methods; 2) plankton diversity; 3) the role of plankton as bioindicator; 4) the linkage between water quality and plankton community.

Table 3. Identification of the findings in the field as material for the utilization of plankton as bio-indicator

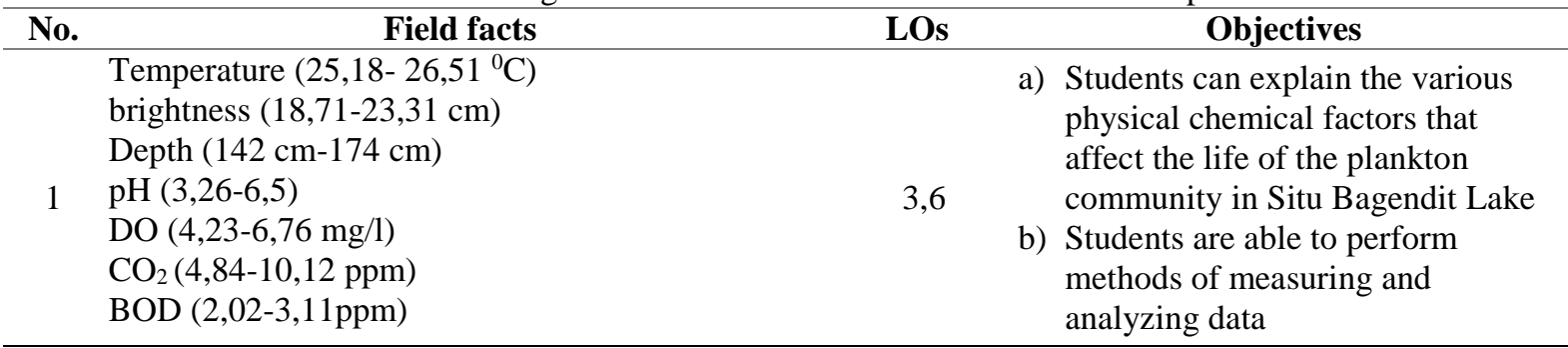

Phytoplankton species were found from five

classes (Bacillariophyceae, Cyanophyceae,

Chlorophyceae, Euglenophyceae, and

2 Xanthophyceae) for a total of 173 individuals. Zooplankton found as many as 5 classes (Rotifera,

Students can explain the diversity of Protozoa, Cladocera, Copepoda and Rotatoria) plankton in Situ Bagendit Lake with a total of 199 individuals.

\begin{tabular}{|c|c|c|c|}
\hline 3 & $\begin{array}{l}\text { Plankton diversity index ranges from } 1.22 \text { to } 2.49 \text {. } \\
\text { The value of plankton dominance index in Situ } \\
\text { Bagendit ranged from } 0.1 \text { to } 0.23 \text {. In Situ } \\
\text { Bagendit water, there was a total abundance of } \\
\text { phytoplankton in the range of } 15.471-25,554 \\
\text { cells/l, while total zoopalankton abundance was } \\
20.864-33,273 \mathrm{sel} / 1 \text {. }\end{array}$ & 3,6 & $\begin{array}{l}\text { Students can explain the diversity of } \\
\text { plankton in Situ Bagendit Lake }\end{array}$ \\
\hline 4 & $\begin{array}{l}\text { Based on the parameters of species composition } \\
\text { and the diversity of inlet type and the middle part } \\
\text { was found Oscillatoria sp. and Anabaena sp } \\
\text { which is kind of phytoplankton. In the inlet and } \\
\text { middle area were found Branchionus sp. }\end{array}$ & $3,6,7$ & $\begin{array}{l}\text { Students can explain the role of } \\
\text { plankton as a bioindicator of water } \\
\text { quality }\end{array}$ \\
\hline 5 & $\begin{array}{l}\text { Inlet area was in medium pollution level and poor } \\
\text { water quality. The middle area was medium } \\
\text { pollution levels and poor water quality. The outlet } \\
\text { area was in level of mild contamination with water } \\
\text { quality is quite good. }\end{array}$ & $3,6,7$ & $\begin{array}{l}\text { Students are able to analyze the } \\
\text { linkages between the quality of } \\
\text { freshwater waters and the plankton } \\
\text { community }\end{array}$ \\
\hline
\end{tabular}

\section{Planning phase}

This teaching material consists of three parts, namely introduction, content, and cover. The introduction contains the title page, the preface, the table of contents, the instruction manual, the concept map and the learning objectives. The content consists of four subsubjects, namely the plankton community in freshwater, physical and chemical factors that affect the life of the plankton in the water, plankton as a bioindicator of water quality, and relationship with the plankton community as well as equipped with problem columns.

The cover section contains a summary of questions, evaluations, answer keys, and bibliography. The results of the design of the issue-based teaching materials include the cover, instructions on the use of teaching materials, table of contents, concept maps, materials, summaries, tests, answer keys, feedback, and bibliography (Prabowo, Nurmiyati, \& Maridi, 2016). The design of teaching materials has been adapted to the curriculum and material concepts that have been established at the definition stage.

\section{Development phase}

Results of feasibility the teaching materials

The teaching materials were validated by the validator include aspects of feasibility, 
appearance, and language. This is similar to the research undertaken by Miharja et al., (2015) who developed the teaching materials judged on the content feasibility aspect, appearance and language.

Assessment of feasibility of issue-based teaching materials on plankton as bio-indicator materials using a modified textbook assessment instrument. Recapitulation of validation issuebased teaching materials by validators is presented in Table 4.
Based on Table 4., it can be seen that the score obtained from a material expert was 35 with an average score as high as 4.37 and the percentage was $87 \%$. This value is included in the "valid/without revision" category. The teaching materials were validated by the validator include aspects of feasibility, appearance, and language. The score from the second validator as high as 63 with an average of 4.5 and the percentage was $84 \%$.

Table 4. Results materials assessment by validator

\begin{tabular}{cllcccc}
\hline No. & Validator & Component & $\begin{array}{c}\text { Acquisition } \\
\text { scores }\end{array}$ & $\begin{array}{c}\text { Average } \\
\text { Score*** }\end{array}$ & $\%$ & Criteria \\
\hline 1 & Content expert & $\begin{array}{l}\text { Content } \\
\text { (feasibility, }\end{array}$ & $35^{*}$ & 4.37 & 87.5 & $\begin{array}{c}\text { Valid/without } \\
\text { revision }\end{array}$ \\
2 & $\begin{array}{l}\text { Learning media } \\
\text { expert 1 }\end{array}$ & $\begin{array}{l}\text { appearance, and } \\
\text { language) } \\
\text { (feasibility, } \\
\text { appearance, and } \\
\text { language) }\end{array}$ & $63^{* *}$ & 4.50 & 84.0 & $\begin{array}{c}\text { Valid/without } \\
\text { revision }\end{array}$ \\
3 & $\begin{array}{l}\text { Learning media } \\
\text { expert 2 }\end{array}$ & Average Overall & 3.64 & 68.0 & $\begin{array}{c}\text { Valid/without } \\
\text { revision }\end{array}$ \\
\hline & & 4.17 & 79.83 & $\begin{array}{c}\text { Valid/without } \\
\text { revision }\end{array}$ \\
\hline
\end{tabular}

Note: $*$ maximum score $=40 ; * *$ maximum score $=75 ; * *$ Score Range $\geq 1.00-5.00$

The score obtained from the third validator was 51 with an average of 3.64 and percentage score was $68 \%$. The second and third validator values are included in the "valid/without revision" category. The overall average score from three validators as high as 4.17 with the category valid/without revision $(79,83 \%)$. Thus, it can be conclude that the teaching materials appropriate with the ASP, so each indicator is precise and measurable.

\section{Results of student responses to teaching materials}

The student responses are consisting of four aspects covering the content, appearance, language, and utility. The responses are presented in Table 5.

Table 5. Summary of student's responses on issue based teaching materials

\begin{tabular}{llcc}
\hline No. Aspects & $\begin{array}{c}\text { Average } \\
\text { Score } \\
(\%)\end{array}$ & Category \\
\hline 1 & Content & 74.13 & Good \\
2 & Appearance & 81.08 & Very good \\
3 & Language & 82.60 & Very good \\
4 & Utility & 84.60 & Very good \\
\hline Average & 80.64 & Very good \\
\hline
\end{tabular}

Based on Table 5., the average score responses from 20 students in content was $74.13 \%$, the appearance was $81.08 \%$, language was $82.6 \%$, and the utility was $84.6 \%$, with an average score as high as $80,64 \%$. This score is included in "good" category, so the teaching material that has been developed is no need to be revised.

Influence of issue-based teaching material on student learning outcomes

The pilot test to examine the effect of issuebased teaching material on students' learning outcomes conducted with as many as 20 students of the Indonesia University of Education, majoring in Biology Education. The process of testing conducted through direct learning activities as listed in the Events Unit Class (EUC) that has been designed. The pilot test results indicate an increase in learning outcomes after the implementation of issuebased teaching materials in learning, presented in Table 6.

Table 6. The average of pretest, posttest, and N-gain of students

\begin{tabular}{ccc}
\hline Pretest & Posttest & N-Gain \\
\hline 60.00 & 86.00 & 0.64 \\
\hline
\end{tabular}


Based on Table 6, the average students' learning outcomes score before the implementation of issue-based teaching material was 60.00 and after the implementation was 86.00 , whereas $\mathrm{N}$-gain that was obtained as high as 0.64 . From the result, students' learning outcomes have improved and based on $\mathrm{N}$-gain, the improvement was in the medium category.

The data were analyzed using the independent t-test. The result of the test is presented in Table 7. After that, based on the result of the independent t-test that can be seen in Table $7, \mathrm{t}$ value that was obtained as high as 18.606 with $p$-value $=0.000$. Therefore the null hypothesis was rejected and it can be concluded the student's learning outcomes after issuebased teaching material implementation was higher than the students' learning outcomes before teaching material implementation. This is in accordance with opinion from Erwanto \& Santos (2016) who said through problem-based learning (issue-based learning is one of problem-based learning variant), student is conditioned to be actively involved in understanding the problems presented, exploring facts and planning for completion, discussing group work, independent learning by doing guesswork, testing answers and summarizing the work, presenting the work, and reviewing the work.

Table 7. The result of independent t-test on the data of students' learning outcomes

\begin{tabular}{|c|c|c|c|c|c|c|c|c|}
\hline \multicolumn{6}{|c|}{ Paired Differences } & \multirow{3}{*}{$\mathbf{t}$} & \multirow{3}{*}{ df } & \multirow{3}{*}{$\begin{array}{l}\text { Sig. (2- } \\
\text { tailed) }\end{array}$} \\
\hline & \multirow{2}{*}{ Mean } & \multirow{2}{*}{$\begin{array}{c}\text { Std. } \\
\text { Deviation }\end{array}$} & \multirow{2}{*}{$\begin{array}{l}\text { Std. Error } \\
\text { Mean }\end{array}$} & \multicolumn{2}{|c|}{$\begin{array}{c}95 \% \text { Confidence } \\
\text { Interval } \\
\end{array}$} & & & \\
\hline & & & & Lower & Upper & & & \\
\hline $\begin{array}{l}\text { Pretest- } \\
\text { posttest }\end{array}$ & -26.00 & 6.249 & 1.397 & -28.925 & -23.075 & -18.606 & 19 & 0.000 \\
\hline
\end{tabular}

The result of this study is in accordance with Aji, Hudha, and Rismawati (2017) who informed that teaching materials can bridge, even combine experiences and learners' knowledge, simple teaching materials can be formulated as anything that can facilitate the participants educated in an effort to obtain some information, knowledge, experience, and skills in teaching and learning process. This research is also supported by Miharja (2015) that informed the students were easy to understand the material by using problem-based teaching materials because of increasing students' interest through the "Problem Column" which is inserted, so the students feel not bored with the material presented.

The problem-solving skills data that were obtained in this study can be seen in Table 8 .
All aspects of problem solving skills have been improving due to the implementation of teaching material that has been developed in this study. During pretest, the categories of student's problem-solving skills in each skill were categorized as good. After the learning process, those aspects have increased to be "good" and "very good" category. This is supported by Diani (2015) that informed the issue-based instruction model is a constructivist-based learning model that accommodates learners' involvement in authentic learning and problem-solving. This result is similar to the results of the study of Anista, Ibrohim, and Suwono (2016) that reported there was an increase in students' critical thinking ability and problem-solving.

Table 8. Percentage of problem-solving skills

\begin{tabular}{clclcc}
\hline No. & \multicolumn{1}{c}{ Aspect PSS } & Pretest & Category & Postest & Category \\
\hline 1 & Formulating problems & 50.80 & Enough & 81.40 & Good \\
2 & Creating hypotheses & 51.90 & Enough & 81.10 & Very good \\
3 & Testing hypotheses & 54.00 & Enough & 80.00 & Good \\
4 & Formulating conclusions & 58.09 & Enough & 82.45 & Very good \\
5 & Implementing conclusions & 45.00 & Enough & 79.10 & Very good \\
\hline \multicolumn{7}{c}{ Average } & 52.12 & & 80.81 & \\
\hline
\end{tabular}

In the 21st-century, one of the roles of biology learning is to empower students' thinking skills (Magsino, 2014; Mcfarlane,
2013), communication skills (Buku, Mite, Fauzi, Widiansyah, \& Anugerah, 2015; Huang et al., 2010; Talat \& Chaudhry, 2014), and 
metacognitive skills (Fauzi, 2013; Ramadani, Fauzi, Sukmawati, \& Corebima, 2015; Tanner, 2012). However, these goals will not be achieved if students have difficulty understanding the concepts they are learning. Not only understand the concepts, the students but also hopefully store their concepts in longterm memory, so they have a good retention on those concepts (Sukmawati, Ramadani, Fauzi, \& Corebima, 2015). Thus, the improving learning outcomes are one goal that should not be forgotten by educators until today (Fauzi, 2013; Husamah \& Pantiwati, 2014; Ramadani et al., 2015). Therefore, one way to optimize the learning process is by improving students' learning outcomes.

Based on the result from this study, the implementation of issue-based teaching materials has been proven could improve students' learning outcomes. This teaching material is the product of the research and development process. Research and development is one kind of research that often conducted by biology educators as the solution to solve some problem in the learning process. Various information can be the basis of the development process, such as various research results in the biology field, based on local wisdom, as well as from environmental conditions and community activity (Setyawan, Rohman, \& Sutomo, 2015). Due to this research have many advantages for improving educational quality, this kind of study is still recommended to be conducted by the researcher in Indonesia.

However, besides studying chemical and biological factors in aquatic environment and utilization of plankton as bio-indicator, the study object of Fresh Water course is various water biotas which size bigger than plankton. In this study, the teaching materials were developed based on observational data of biological and chemical condition in Situ Bagendit Lake and the diversity of plankton in that location. Various biotas, such as macroinvertebrates (Nuha et al., 2015; Sukoco et al., 2015; Wijayanti et al., 2015), various algaes and plants (Maznah, Omar, Pinang, Biologi, \& Biologi, 2010), to fish (Naigaga et al., 2011) are actually also the water biota that is often found and also become the bioindicator of aquatic environment. Therefore, the development of teaching materials that discusses other biota conditions is also recommended for further research.

\section{CONCLUSION}

Issue-based teaching materials have been developed. Based on validation result by content expert and media expert, the teaching material was valid and can implement without revision. The validation results are in line with the student's response. After that, the implementation of the teaching material on student could improve students' learning outcome, both in the aspect of mastery the concepts and problem-solving skills. However, the use of issue-based teaching materials takes a long time. Therefore, it is necessary to study the time planning at the beginning of the semester before the learning begins so that the implementation process can running well.

\section{REFERENCES}

Aji, S. D., Hudha, M. N., \& Rismawati, A. Y. (2017). Pengembangan modul pembelajaran fisika berbasis problem based learning untuk meningkatkan kemampuan pemecahan masalah fisika. Science Education Journal, 1(1), 36-51. https://doi.org/10. 21070/sej.v1i1.830

Anista, W., Ibrohim, \& Suwono, H. (2016). Pengembangan perangkat pembelajaran berbasis penelitian uji hayati untuk meningkatkan kemampuan berpikir kritis dan pemecahan mahasiswa program studi pendidikan biologi untag banyuwangi. Jurnal Pendidikan: Teori, Penelitian, Dan Pengembangan, 1(9), 1684-1687.

Bahri, S., Syamsuri, I., \& Mahanal, S. (2016). Pengembangan modul keanekaragaman hayati dan virus berbasis model inkuiri terbimbing untuk siswa Kelas X. Jurnal Pendidikan: Teori, Penelitian, Dan Pengembangan, 1(2), 127-136.

Brickell, G., Hedberg, P. J., Ferry, D. B., \& Harper, P. B. (2001). Problem solving strategies-Is there a better way? In World Conference on Educational Multimedia, Hypermedia and Telecommunications 2001 (pp. 197-198).

Buku, M. N. I., Mite, Y., Fauzi, A., Widiansyah, A. T., \& Anugerah, D. Y. (2015). Penerapan pembelajaran cooperative script berbasis lesson study sebagai upaya peningkatan keaktifan lisan dan kecakapan sosial mahasiswa SI Pendidikan Biologi matakuliah strategi belajar mengajar. In Proceedings of the 
2nd Seminar \& Workshop Nasional Biologi, IPA, dan Pembelajarannya FMIPA UM (pp. 603-606). Malang: Biologi FMIPA UM.

Çimer, A. (2012). What makes biology learning difficult and effective: Students' views. Educational Research and Reviews, 7(3), 61-71. https://doi.org/10.5897/ERR11.205

Diani, R. (2015). Pengembangan perangkat pembelajaran fisika berbasis pendidikan karakter dengan model problem based instruction. Jurnal Ilmiah Pendidikan Fisika Al-BiRuNi, 04(2), 241-253. https://doi.org/10.24042/jpifalbiruni.v4i2. 96

Elder, A. D. (2015). Using a brief form of Problem-Based Learning in a research methods class: Perspectives of instructor and students. Journal of University Teaching and Learning Practice, 12(1), 13.

Erwanto, U., \& Santoso, E. (2016). Pengembangan modul pembelajaran berbasis masalah untuk membantu meningkatkan berfikir kreatif mahasiswa. Jurnal Inovasi Pembelajaran, 2(2), 427436.

Etobro, A. B., \& Fabinu, O. E. (2017). Students ' Perceptions of Difficult Concepts in Biology in Senior Secondary Schools in Lagos State. Global Journal of Educational Research, 16, 139-147.

Fauzi, A. (2013). Pengaruh kemampuan akademik terhadap keterampilan metakognitif, hasil belajar biologi, dan retensi siswa SMA Kelas $X$ dengan penerapan strategi pembelajaran cooperative script di Malang. Universitas Negeri Malang. https://doi.org/10.13140/ RG.2.2.24659.99363

Fauzi, A. (2017). Analisis filogeni Tarsius tarsier form Buton dengan beberapa spesies tarsius dari Sulawesi Tengah, Sumatera-Kalimantan, dan Filipina atas dasar Gen MT-CO2 sebagai bahan pengembangan buku panduan penelitian Mata Kuliah Genetika II di Universitas Negeri Mal. Universitas Negeri Malang.

Feng, L., Hu, C., Chen, X., Tian, L., \& Chen, L. (2012). Human induced turbidity changes in Poyang Lake between 2000 and 2010: Observations from MODIS. Journal of Geophysical Research: Oceans, 117(C7), n/a-n/a.

https://doi.org/10.1029/2011JC007864
Government regulation of The Republic of Indonesia Number 82 year 2001 on water quality management and water pollution control (2001). Indonesia.

Hill, A. M. (1998). Problem solving in real-life contexts: An alternative for design in technology education. International Journal of Technology and Design Education, 8, 203-220. Retrieved from http://link.springer.com/content/pdf/10.10 23/A:1008854926028.pdf

Huang, D., Leon, S., Hodson, C., La, D., Obregon, T. N., \& Rivera, G. (2010). Preparing students for the 21st century: Exploring the effect of afterschool participation on students' collaboration skills, oral communication skills, and selfefficacy. Los Angeles. https://doi.org/10. 1037/e642072011-001

Hunaepi, Kurnia, N., \& Firdaus, L. (2014). Validasi buku ajar ekologi berbasis kearifan lokal untuk mengembangkan sikap ilmiah mahasiswa. Pengkajian Ilmu Dan Pembelajaran, 4(2), 174-181.

Husamah, \& Pantiwati, Y. (2014). Cooperative learning STAD-PjBL: Motivation, thinking skills, and learning outcomes of Biology Department students. International Journal of Education Learning and Development, 2(1), 77-94.

Johan, T. I. (2011). Dampak penambangan emas terhadap kualitas air Sungai Singingi di Kabupaten Kuantan Singingi Provinsi Riau. Ilmu Lingkungan, 5(2), 168-183.

Magsino, R. M. (2014). Enhancing higher order thinking skills in a marine biology class through Problem-Based Learning. Asia Pacific Journal of Multidisciplinary Research, 2(5), 1-6.

Maznah, W., Omar, W., Pinang, P., Biologi, P., $\&$ Biologi, P. (2010). Perspectives on the use of algae as biological indicators for monitoring and protecting aquatic environments, with special reference to Malaysian freshwater ecosystems. Tropical Life Sciences Research, 21(2), 51-67.

Mcfarlane, D. A. (2013). Understanding the challenges of science education in the 21 st Century: New opportunities for Scientific Literacy. International Letters of Social and Humanistic Sciences, 4, 3544. https://doi.org/10.18052/www.scipress .com/ILSHS.4.35

Miharja, F. J., Syamsuri, I., \& Saptasari, M. 
(2015). Pengembangan modul anatomi fisiologi manusia dengan model pembelajaran berbasis masalah untuk meningkatkan kompetensi mahasiswa program studi pendidikan biologi. In Prosiding Seminar Nasional Pendidikan Biologi (pp. 220-227).

Monica Z. Bruckner. (2018). Measuring lake turbidity using a secchi disk. Retrieved July 23, 2018, from https://serc.carleton. edu/microbelife/research_methods/enviro n_sampling/turbidity.html

Naigaga, I., Kaiser, H., Muller, W. J., Ojok, L., Mbabazi, D., Magezi, G., \& Muhumuza, E. (2011). Fish as bioindicators in aquatic environmental pollution assessment: A case study in Lake Victoria wetlands, Uganda. Physics and Chemistry of the Earth, 36(14-15), 918-928. https://doi. org/10.1016/j.pce.2011.07.066

Nuangchalerm, P. (2009). Development of socioscientific issues-based teaching for preservice science teachers. Journal of Social Sciences, 5(3), 239-243.

Nuangchalerm, P., \& Kwuanthong, B. (2017). Teaching "global warming" through socioscientific issues-based instruction. Asian Social Science, 6(8), 42-47.

Nuha, U., Sukoco, R. M., Anajili, H., Fauzi, A., Mustofa, Z., \& Mite, Y. (2015). eksplorasi keanekaragaman makroinvertebrata akuatik di kawasan Coban Trisula Kabupaten Malang. In Proceedings of the 2nd Seminar \& Workshop Nasional Biologi, IPA, dan Pembelajarannya FMIPA UM (pp. 66-71). Malang: Biologi FMIPA UM.

Ogunkola, B., \& Samuel, D. (2011). Science Teachers' and Students' Perceived Difficult Topics in the Integrated Science Curriculum of Lower Secondary Schools in Barbados. World Journal of Education, 1(2), 17-29. https://doi.org/10.5430/wje. $\mathrm{v} 1 \mathrm{n} 2 \mathrm{p} 17$

Permana, T. I., Suwono, H., \& Listyorini, D. (2016). Pengaruh pembelajaran berbasis masalah penyakit tropis terhadap kecakapan hidup siswa SMA. Jurnal Pendidikan: Teori, Penelitian, Dan Pengembangan, 1(6). Retrieved from https://scholar.google.co.id/citations?hl=e n\&user=Eh-8zbkAAAAJ

Prabowo, D. L., Nurmiyati, \& Maridi. (2016). Pengembangan modul berbasis potensi lokal pada materi ekosistem sebagai bahan ajar di SMA N 1 Tanjungsari, Gunungkidul. In Proceeding Biology Education Conference (Vol. 13, pp. 192195). Surakarta: Pendidikan Biologi FKIP UNS.

Presley, M. L., Sickel, A. J., Muslu, N., Merle-, D., Witzig, S. B., Izci, K., \& Sadler, T. D. (2013). A framework for socio-scientific issues based education. Science Educator, 22(1), 26-32.

Ramadani, S. D., Fauzi, A., Sukmawati, I., \& Corebima, A. D. (2015). Perbandingan potensi strategi pembelajaran cooperative script dan reciprocal teaching dalam memberdayakan keterampilan metakognitif, hasil belajar Biologi, dan retensi siswa SMA. In Proceedings of the 2nd Seminar \& Workshop Nasional Biologi, IPA, dan Pembelajarannya FMIPA UM (pp. 655-661). Malang: Biologi FMIPA UM.

Setyawan, D., Rohman, F., \& Sutomo, H. (2015). Kajian etnozoologi masyarakat Desa Hadiwaarno Kabupaten Pacitan dalam konservasi penyu sebagai bahan penyusunan booklet penyuluhan masyarakat. JPB, 1(3), 283-297. https://doi.org /10.22219/jpbi.v1i3.2661

Sukmawati, I., Ramadani, S. D., Fauzi, A., \& Corebima, A. D. (2015). Perbedaan pemberdayaan retensi antara siswa sma akademik rendah dan tinggi melalui pembelajaran cooperative script dalam pembelajaran biologi. In Proceedings of the 2nd Seminar \& Workshop Nasional Biologi, IPA, dan Pembelajarannya FMIPA UM (pp. 662-667). Malang: Biologi FMIPA UM.

Sukoco, R. M., Fadilah, R. E., Widiansyah, A. T., Wijayanti, E., Mustofa, Z., \& Fauzi, A. (2015). Inventarisasi makroinvertebrata akuatik di kawasan Coban Jahe Kabupaten Malang. In Proceedings of the 2nd Seminar \& Workshop Nasional Biologi, IPA, dan Pembelajarannya FMIPA UM (pp. 60-65). Malang: Biologi FMIPA UM.

Susilana, R., \& Riyana, C. (2009). Media pembelajaran. Bandung: CV Wacana Prima.

Talat, A., \& Chaudhry, H. F. (2014). The effect of PBL and 21st century skills on students' creativity and competitiveness in private schools. The Lahore Journal of Business, 2(2), 89-114. 
Kamaludin et al. / JPBI (Jurnal Pendidikan Biologi Indonesia) / 4 (2) (2018) pp. 161-170

Tanner, K. D. (2012). Promoting student metacognition. CBE Life Sciences Education, 11(2), 113-120. https://doi. org/10.1187/cbe.12-03-0033

Topçu, M. S., \& Şahin-Pekmez, E. (2009). Turkish middle school students' difficulties in learning genetics concepts. Journal of Turkish Science Education, $6(2), 55-62$.

Widiansyah, A. T., Indriwati, S. E., Munzil, \& Fauzi, A. (2018). I-invertebrata as an android-based learning media for molluscs, arthropods, and echinoderms identification and its influence on students' motivation. JPBI (Jurnal Pendidikan Biologi Indonesia), 4(1), 4352.https://doi.org/10.22219/jpbi.v4i1.5476 Wijayanti, E., Fauzi, A., Widiansyah, A. T., Mustofa, Z., Setyanto, A., Sukoco, R. M., ... Fadilah, R. E. (2015). The inventory of aquatic macroinvertebrates in various waterfall in east region of Malang, East Java. In E. L. Arumingtyas (Ed.), Proceeding of 6th ICGRC (pp. 150-153). Malang: Department of Biology, Faculty of Sciences Brawijaya University. 